\title{
ANALISIS DAN EVALUASI SISTEM INFORMASI GEOGRAFIS PARIWISATA PROPINSI PAPUA
}

\author{
Ari Widiastono ${ }^{1}$, Liza Angriani ${ }^{2}$ \\ 1ari.widiastono@amikumelmandiri.ac.id, ${ }^{2}$ liza.angriani@amikumelmandiri.ac.id \\ ${ }^{1,2}$ AMIK Umel Mandiri
}

\begin{abstract}
Abstrak
Propinsi Papua mempunyai banyak sekali obyek wisata antara lain obyek wisata alam, wisata sejarah, wisata budaya, wisata minat khusus, wisata kuliner, wisata olah raga, wisata belanja, dan wisata bahari. Namun kurangnya informasi menyebabkan wisatawan tidak mengetahui adanya tempat-tempat wisata yang menarik dan indah. Untuk mengatasi permasalahan ini, salah satunya dapat menggunakan Sistem Informasi Geografis (SIG) untuk mengetahui titik lokasi obyek dan daya tarik wisata di Propinsi Papua. Metode pengumpulan data yang digunakan adalah Kuesioner. Hasil penelitian ini adalah Website Dinas Pariwisata dan Ekonomi Kreatif Propinsi Papua sudah cukup memadai tetapi masih ada kekurangan yang perlu diperbaiki dalam pengembangan sebuah website yang interaktif. struktur menu pada website perlu diperbaharui karena kurangnya menu utama website ini berupa menu wisata yang terdiri dari wisata bahari, wisata alam, wisata budaya, wisata kuliner, dan wisata sejarah serta Tempat/Objek Wisata favorit untuk dipajang di Website untuk memberikan banyak informasi pada masyarakat tentang pariwisata di Propinsi Papua.
\end{abstract}

Kata kunci: Obyek dan Daya Tarik Wisata, Papua, Pariwisata, Sistem Informasi Geografis

\section{Pendahuluan}

Papua adalah propinsi ke 26 (dua puluh enam) dari Negara Kesatuan Republik Indonesia dengan ibu kotanya Jayapura, berpenduduk $\pm 2,9$ juta jiwa, terletak di wilayah tertimur Indonesia, menawarkan berbagai jenis obyek dan daya tarik wisata, seperti: kemurnian alam, tumbuhan dan hewan, bahari, budaya, tradisi, gaya hidup masyarakat dari banyak etnis dan ras yang mana terdapat \pm 271 bahasa daerah yang terbagi dalam 7 (tujuh) wilayah adat (Papua-Papua Barat), hutan lebat, sungai besar, lembah-lembah indah, dan pegununggan salju abadi yang kesemuanya itu merupakan keunikan Papua.

Penelitian sebelumnya menghasilkan data lokasi pariwisata di Propinsi Papua dan mendapatkan informasi dari masyarakat tentang sejauhmana sistem informasi geografis yang telah ada di Dinas Pariwisata Propinsi Papua memuaskan kebutuhan masyarakat akan informasi Pariwisata di Propinsi Papua serta saran untuk perbaikan sistem informasi geografis tersebut untuk pengembangannya sesuai dengan keinginan masyarakat [6].

Propinsi Papua mempunyai banyak sekali obyek dan daya tarik wisata antara lain obyek wisata alam, wisata sejarah, wisata budaya, wisata minat khusus, wisata kuliner, wisata olah raga, wisata belanja, dari sekian banyak obyek dan daya tarik wisata Propinsi Papua yang sangat terkenal yaitu wisata alam Danau Paniai. Obyek wisata alam (pantai, sungai, danau, air terjun, hutan, gunung, gua, pulau, taman nasional), wisata sejarah (prasasti, candi, istana, benteng, makam, rumah ibadah, museum monumen), wisata budaya (upacara adat/ritual, seni pertunjukan), wisata religius, wisata kuliner (makanan khas), wisata khusus (arsitek, kota, pendidikan, kebun binatang, SPA), wisata olah raga (moderen, tradisonal), wisata belanja (moderen, tradisional), wisata umum, dan lain-lain [1], [2], [3].

Tidak hanya itu, masih banyak obyek dan daya tarik wisata lainnya yang patut dikunjungi. Namun kurangnya informasi menyebabkan wisatawan tidak mengetahui adanya obyek dan daya tarik wisata yang menarik dan indah. Untuk mengatasi permasalahan ini, salah satunya dapat menggunakan Sistem Informasi Geografis (SIG) yang merupakan langkah tepat untuk mengetahui titik lokasi obyek dan daya tarik wisata yang terdapat di Propinsi Papua [4], [5], [7].

\section{Metode}

Penelitian ini menggunakan metode penelitian deskriptif karena dalam pelaksanaannya meliputi data, analisis, dan interpretasi tentang arti dan data yang diperoleh. Penelitian ini disusun sebagai penelitian induktif yakni mencari dan mengumpulkan data yang ada di lapangan dengan tujuan untuk mengetahui dan mengumpulkan informasi dari masyarakat tentang sejauhmana sistem informasi yang telah ada di Dinas Pariwisata Propinsi Papua dapat memuaskan kebutuhan masyarakat akan 
informasi pariwisata di Propinsi Papua serta saran untuk perbaikan sistem informasi tersebut untuk pengembangannya sesuai dengan keinginan masyarakat.

Dalam penelitian ini metode pengumpulan data yang digunakan adalah kuesioner. Kuesioner adalah teknik pengumpulan data melalui formulir-formulir yang berisi pertanyaan-pertanyaan yang diajukan secara tertulis pada seseorang atau sekumpulan orang untuk mendapatkan jawaban atau tanggapan dan informasi yang diperlukan oleh peneliti. Daftar pertanyaannya dibuat secara berstruktur dengan bentuk pertanyaan pilihan berganda (multiple choice questions) dan pertanyaan terbuka (open question). Metode ini digunakan untuk memperoleh data tentang persepsi dari responden tentang sistem informasi tersebut.

Parameter penilaian/pertanyaan pilihan berganda (multiple choice questions) sistem informasi geografis terdiri dari:

1. Homepage, kriteria penilaiannya antara lain:
a. Halaman depan website mudah dimengerti dan dipahami
b. Memilki banner ucapan selamat datang
c. Desain halaman depan website
d. Desain layout (tata letak)
e. Huruf mudah dibaca
f. Struktur menu yang disajikan

2. Isi (Contents), kriteria penilaiannya antara lain:
a. Kualitas website
b. Relevan website
c. Manfaat konten website
d. Berita (news)
e. Profil daerah
f. Gallery
g. Agenda festival
h. Info kota

3. Konteks, kriteria penilaiannya antara lain:
a. Ada visi dan misi pemerintah daerah
b. Tugas pokok dan fungsi lembaga pemerintahan
c. Terdapat informasi geografis
d. Terdapat informasi potensi daerah
e. Terdapat link dengan website lain yang terkait (dinas, badan, dan kantor)
f. Konten website sesuai dengan visi dan misi
g. Terdapat informasi layanan publik
h. Berita
i. Profil instansi

4. Ukuran kualitas interaksi (Usability), kriteria penilaiannya antara lain:
a. Ada ruang komunikasi
b. Kualitas interaksi pelayanan
c. Tampilan mudah dimengerti (user friendly)
d. Alamat website mudah untuk diingat

5. Kemudahan dibaca (Readibility), kriteria penilaiannya antara lain:
a. Mudah dibaca, dimengerti, dan dipahami (informasi yang ada)
b. Kejelasan kalimat dalam tulisan
c. Tata letak teks
d. Warna tulisan
e. Menggunakan multi bahasa
f. Kemudahan dalam mencari informasi
g. Navigasi dan fitur yang ditawarkan sudah mencukupi dan memudahkan

6. Mobilitas data, kriteria penilaiannya antara lain:
a. Informasi dan data selalu update
b. Tracking (pencarian data lawas)
c. Data akurat
d. Tersedia data-data yang lalu

7. Ketepatan (Accuracy), kriteria penilaiannya antara lain:

a. Reabilitas data (ketepatan data)

b. Informasi yang valid 


\section{ILKOM Jurnal IImiah Volume 10 Nomor 1 April 2018}

c. Sumber informasi jelas

8. Layanan Publik, kriteria penilaiannya antara lain:
a. Informasi Publik
b. Informasi yang Lengkap
c. Layanan dan Keluhan Publik
d. Contact Us

9. Penggunaan Platform: kriteria penilaiannya antara lain:
a. Dukungan browser
b. Dukungan sistem operasi
c. Dukungan plug-in (aplikasi web)

Bobot/skor penilaian kuesioner terdiri dari:

1. Sangat baik (SB) bobot/skornya 5

2. Baik (B) bobot/skornya 4

3. Cukup baik (CB) bobot/skornya 3

4. Kurang baik (KB) bobot/skornya 2

5. Sangat kurang baik (SKB) bobot/skornya 1

Pertanyaan terbuka (open question) antara lain:

1. Bentuk pariwisata yang perlu dikembangkan di Propinsi Papua

2. Bentuk wisata bahari yang perlu dikembangkan di Propinsi Papua.

3. Bentuk wisata budaya yang perlu dikembangkan di Propinsi Papua.

4. Bentuk wisata sejarah yang perlu dikembangkan di Propinsi Papua.

5. Bentuk wisata alam yang perlu dikembangkan di Propinsi Papua.

6. Bentuk wisata kuliner yang perlu dikembangkan di Propinsi Papua.

7. Informasi tempat/objek wisata apa yang diinginkan untuk dipajang di Website Pariwisata Propinsi Papua.

Kuesioner disebarkan kepada 40 (empat puluh) orang responden. Jumlah kuesioner yang disebarkan dan terkumpul dapat dilihat pada Tabel 1.

Tabel 1. Jumlah Kuesioner

\begin{tabular}{ccc}
\hline Responden Kuesioner & Kuesioner yang disebarkan & Kuesioner yang terkumpul \\
\hline Masyarakat & 20 & 12 \\
Mahasiswa & 20 & 18 \\
\hline Total & 40 & 30
\end{tabular}

\section{Hasil dan Pembahasan}

Tampilan Website Dinas Pariwisata dan Ekonomi Kreatif Propinsi Papua dapat dilihat pada Gambar 1a, 1b, dan 1c.

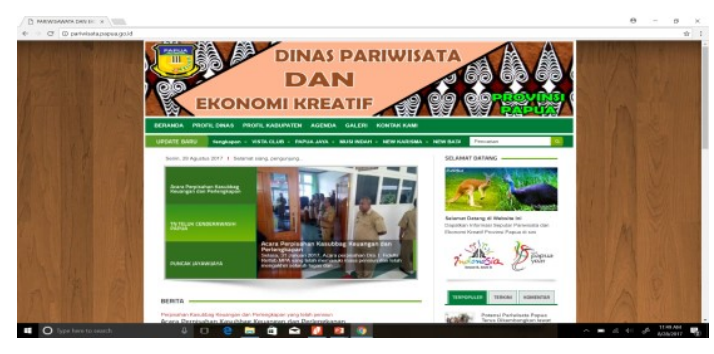

(a)

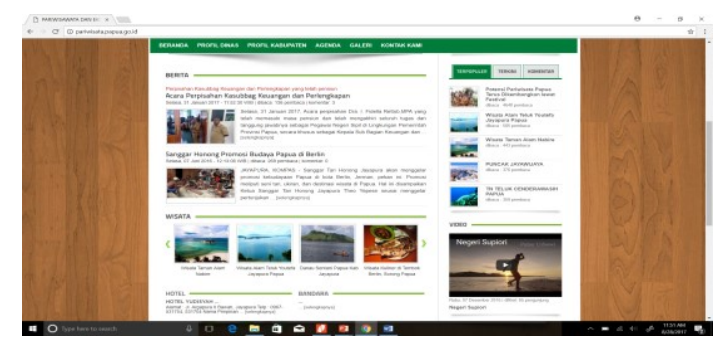

(b)

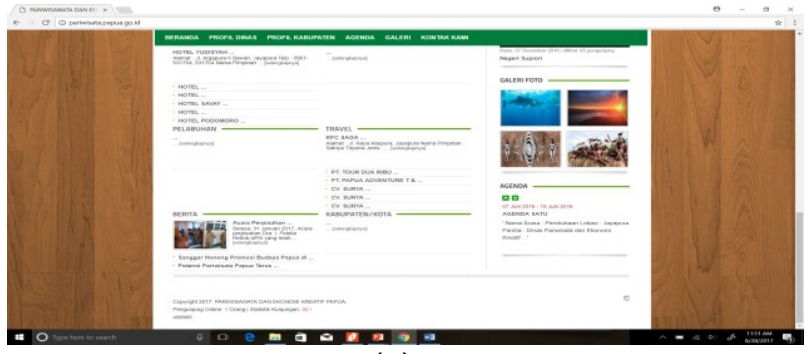

(c) 
Gambar 1. Tampilan Website Dinas Pariwisata dan Ekonomi Kreatif Propinsi Papua Hasil Analisis dan Evaluasi Sistem Informasi Geografis Pariwisata Propinsi Papua dapat dilihat pada Tabel 2.

Tabel 2. Hasil Analisis dan Evaluasi Sistem Informasi Geografis Pariwisata Propinsi Papua

\begin{tabular}{llc}
\hline NO. & \multicolumn{1}{c}{$\begin{array}{c}\text { PARAMETER } \\
\text { PENILAIAN }\end{array}$} & KRITERIA PENILAIAN \\
\cline { 3 - 3 } 1. & Homepage & RATA-RATA TERTINGGI \\
2. & Contents & 4,27 \\
3. & Konteks & 4,13 \\
4. & Usability & 4,27 \\
5. & Readibility & 4,13 \\
6. & Mobilitas data & 4,20 \\
7. & Accuracy & 3,73 \\
8. & Layanan publik & 4,07 \\
9. & Penggunaan platform & 3,87 \\
\hline
\end{tabular}

Berdasarkan kuesioner yang disebarkan ke responden dihasilkan nilai rata-rata baik. Namun menurut peneliti:

1. Struktur menu pada website perlu diperbaharui karena kurangnya menu utama website ini berupa menu wisata yang terdiri dari wisata bahari, wisata alam, wisata budaya, wisata kuliner, dan wisata sejarah untuk memberikan banyak informasi pada masyarakat tentang pariwisata di Propinsi Papua.

2. Profil daerah, galery, agenda festival, dan info kota pada website fungsinya perlu diperjelas lagi, karena informasi yang dibutuhkan masyarakat dari 4 (empat) hal tersebut kurang memadai.

3. Masih ada kekurangan dalam hal berita yang disajikan jarang diperbaharui.

4. Website perlu diperbaharui pada kualitas interaksi pelayanan, di mana perlunya menambahkan fasilitas chat agar pelayanan lebih interaktif.

5. Perlu adanya fitur multi Bahasa, untuk memudahkan calon wisatawan asing untuk dapat memahami isi konten dari website.

6. Perlu adanya perbaikan secara menyeluruh, karena jarangnya perbaharuan informasi wisata baru atau event wisata yang ada di Papua.

7. Framework website perlu diperbaharui karena perlunya perbaikan tampilan website jika diakses menggunakan smartphone.

Sedangkan untuk parameter penilaian/pertanyaan terbuka (open question) adalah pariwisata yang perlu dikembangkan di Propinsi Papua adalah wisata alam. Wisata bahari yang perlu dikembangkan di Propinsi Papua adalah memancing. Wisata budaya yang perlu dikembangkan di Propinsi Papua adalah tarian adat dan 4 kehidupan lokal. Wisata sejarah yang perlu dikembangkan di Propinsi Papua adalah museum budaya. Wisata alam yang perlu dikembangkan di Propinsi Papua adalah keindahan alam/topografi. Wisata kuliner yang perlu dikembangkan di Propinsi Papua adalah makanan tradisional. Informasi tempat/objek wisata yang diinginkan untuk dipajang di Website Pariwisata Propinsi Papua adalah Pantai Pasir VI Jayapura.

\section{Kesimpulan dan Saran}

Website Dinas Pariwisata dan Ekonomi Kreatif Propinsi Papua sudah cukup memadai berdasarkan kuesioner yang disebarkan ke responden tetapi masih ada kekurangan yang perlu diperbaiki. Kekurangan yang perlu diperbaiki dalam hal pengembangan sebuah website yang interaktif. struktur menu pada website perlu diperbaharui karena kurangnya menu utama website ini berupa menu wisata yang terdiri dari wisata bahari, wisata alam, wisata budaya, wisata kuliner, dan wisata sejarah serta Tempat/Objek Wisata favorit untuk dipajang di Website untuk memberikan banyak informasi pada masyarakat tentang pariwisata di Propinsi Papua. Adapun saran untuk hasil analisis dan evaluasi ini adalah perlu merancang suatu Sistem Informasi Geografis Pariwisata Propinsi Papua. 


\section{ILKOM Jurnal Ilmiah Volume 10 Nomor 1 April 2018}

\section{Terima Kasih}

Terima kasih kepada Direktorat Riset dan Pengabdian kepada Masyarakat Direktorat Jenderal Penguatan Riset dan Pengembangan Kementerian Riset, Teknologi, dan Pendidikan Tinggi Republik Indonesia yang telah memberikan dana hibah Penelitian Dosen Pemula Tahun Anggaran 2017.

\section{Daftar Pustaka}

[1] Ardi Dwi Saputra I.S. dan Yulmaini. 2012. Perancangan Sistem Informasi Geografis (SIG) Pariwisata di Provinsi Lampung Informatics and Business Institute Darmajaya. Jurnal Informatika. Vol. 12, No. 2, Desember 2012.

[2] Dewi Soyusiawaty, Rusydi Umar, dan Rochmat Mantofani. 2007. Sistem Informasi Geografis Objek Wisata Propinsi Kepulauan Bangka Belitung Berbasis Web. SNATI. 16 Juni 2007, ISSN: 1907-5022. Halaman 17-22. Yogyakarta.

[3] Dinas Pariwisata dan Ekonomi Kreatif Propinsi Papua. 2014. Home of Tribes, Land of Adventure. Informasi Pariwisata \& Ekonomi Kreatif. Halaman 1-2. Jayapura.

[4] Chang, Kang Tsung. 2008. Introduction to Geographic Information Systems. McGraw Hill International Edition. Page 1. New York.

[5] Mashita Enggar Kusuma dan Yanto Budisusanto. 2015. Aplikasi Google Maps API Dalam Pengembangan Sistem Informasi Geografis (SIG) Pariwisata Berbasis Web (Studi Kasus : Kabupaten Sidoarjo), GEOID. Vol. 10, No. 02, Februari 2015. Halalaman 129-136.

[6] Widiastono, Ari dan Liza Angriani. 2017. Analisis Sistem Informasi Geografis Pariwisata Propinsi Papua. SEMNASTIKOM. Universitas Yapis Papua. ISBN: 978-602-50434-0-6. Halaman 50-54. Jayapura.

[7] Riyanto, dkk. 2009. Pengembangan Aplikasi Sistem Informasi Geografis Berbasis Desktop dan Web. Gava Media. Halaman 32-33. Yogyakarta. 